\title{
The Effect of Resource-Based Instructions on Pre-service Biology Teachers' Attitudes towards Learning Biology
}

\author{
Josiane Mukagihana \\ African Centre of Excellence for Innovative Teaching and Learning Mathematics \\ and Science (ACEITLMS), \\ University of Rwanda-College of Education (URCE), Rwanda \\ https://orcid.org/0000-0001-7334-331X \\ Catherine M. Aurah \\ Masinde Muliro University, of Science and Technology, Kenya \\ https://orcid.org/0000-0002-0781-3202 \\ Florien Nsanganwimana \\ African Centre of Excellence for Innovative Teaching and Learning Mathematics \\ and Science (ACEITLMS), \\ University of Rwanda-College of Education (URCE), Rwanda \\ https://orcid.org/0000-0002-3152-9893
}

\begin{abstract}
A positive attitude correlates to successful learning, while a negative attitude leads to poor learning. The present study aimed to compare the pre-service biology teachers' attitudes towards learning biology and assessing their attitude change before and after being taught by resource-based instructions (RBI) in Rwanda. A survey research design was used, in combination with a quasi-experimental control group and the equivalent time-series designs. Pre-service biology teachers were taught at a public university in three separate groups, with one control group and two experimental groups. Each group received a pre-attitude and a post-attitude assessment. In contrast, at a private university, they were taught as a single group, in a series of instructions, starting with the lecture method, followed by animation-based instruction and smallgroup laboratory activities, in which at each stage, the pre-service biology teachers received the same assessment. The biology Attitude Scale showed a Cronbach alpha reliability of 0.625 before its use. The data were analyzed quantitatively, and the results revealed no statistically significant difference between the public and the private pre-service teachers' attitudes before learning microbiology. Basically, the results show that pre-service biology teachers at the private University had much more positive attitudes than those in a public university. Contrary to the private university, pre-service teachers' attitudes towards biology
\end{abstract}


changed after instruction in all groups across all the attitudinal statements at the public university. Nevertheless, all methods used during the intervention, namely the lecture methods, animation-based instructions, and small-group laboratory activities, equally improved pre-service biology teachers' attitudes towards learning biology. The lack of statistically significant difference among methods suggests that the preservice teachers' attitudes towards learning biology could also be influenced by other factors including their maturity level as well as their anticipated career commitment.

Keywords: attitude scale; biology; pre-service biology teachers; resourcebased instructions

\section{Introduction}

Students' attitude towards learning is an essential cognitive behavior that contributes more to their learning outcomes, such as academic achievement, engagement with subject learning, and concept understanding (Prokop, Tuncer, et al., 2007). Hussein (2017) proved that attitude significantly improves students' intention to use instructional tools, like technology-related instructions, such as elearning. Students' attitude determines their behavioral differences towards a given subject or concepts (Haddock, 2017); therefore, understanding students' attitudinal changes after teaching and learning is essential for improving the quality of education. Studies done in Rwanda have shown that secondary-school students feel bored with learning physics; since they think that it does not relate to any real-world experiences (Mbonyiryivuze et al., 2021); moreover, some studies found that students lose interest in learning mathematics due to the instructional tools used by their teachers (Ukobizaba et al., 2020).

Although attitude has been defined by many studies differently, all are of the same opinion that attitude is the expression of the inner feelings of an individual that may be perceived as a behavior of liking or disliking a particular thing (Shrigley et al., 1988, Lovelace \& Brickman, 2013; Musengimana et al., 2021; Prokop, Prokop, et al., 2007; Prokop, Tuncer, et al., 2007; Tikka et al., 2000). Attitude is an individual mental state that characterizes his or her experiences of consistently responding to environmental phenomena. In its dimensions, attitude is conceptualized as being cognitive, which is the belief in an object as being affective, which reflects the favorability or the availability of an object and the behavioral intentions and the expression of intention towards the object (Kiecolt, 1988).

The word attitude may be used interchangeably to refer to one's belief, opinion, or value. Furthermore, an individual's attitude can be perceived in two opposite behaviors: positive and negative, and these can be influenced by different factors (Shrigley et al., 1988). Several factors, such as the instructional methods (Mukagihana et al., 2020, 2021a), gender, students' interest, and classroom environment, were pointed out to affect students' attitudes towards scientific subjects, including chemistry (Musengimana et al., 2021). 
Various instructional methods have been used to test their influence on students' attitude towards scientific subjects, and among others, co-operative learning methods, computer-assisted instruction, problem-based active learning, mediabased instruction, simulation-assisted laboratory instruction, and instructional technology and material-design course, which positively affected students, including pre-service science teachers' attitude towards science learning (Akinoğlu \& Tandoğan, 2007; Çepni et al., 2006; McManus et al., 2003; Rabgay, 2018, Calik-Uzun, Selcen, et al., 2019, Selçuk, 2010a; Ulukök \& Sari, 2016, Bektaşli, 2013). Many of these instructions are applied in the resource-supported learning environment, and they are referred to as resource-based instructions, such as computer-assisted instructions, simulation-assisted laboratory instruction, instructional technology, and material-design courses. With resource-based instructions, the teaching and learning process uses a single instruction or a variety of instructional resources; and students learn by using these resources (Butler, 2012). Resource-based instructions promote students' active participation by learning in real and tangible learning environments, allow them to interact with instructional resources through hands-on activities, and discovering knowledge and facts themselves. Hence, they enhance students' learning outcomes and their attitude changes towards learning science (Hill \& Hannafin, 2001).

A good number of studies focused on the students' attitude towards learning science in general (Rabgay, 2018, Calik-Uzun, Selcen, et al., 2019, Selçuk, 2010a; Ulukök \& Sari, 2016, Bektaşli, 2013); but a few of these studies emphasized the pre-service biology teachers' attitude towards learning biology. Furthermore, only a few of the current studies focused on the effect of instructional methods on preservice biology teachers' attitude towards learning biology; however, the effect of resource-based instructions, especially animation-based instruction and laboratory methods through small-group laboratory activities on pre-service biology teachers' attitudes towards learning biology, was not highlighted. With such observations made in the current literature, the present study aimed to find out the pre-service biology teachers'attitudes towards learning biology in higher learning institutions in Rwanda.

It also aimed to find out the effect of resource-based instructions on pre-service biology teachers' attitudes towards learning biology in higher learning institutions in Rwanda, with three main objectives: (1) to compare the pre-service biology teachers' attitude towards learning biology at private and public science teacher-training universities; (2) to assess the change in pre-service biology teachers' attitudes towards learning biology after learning via animations and small-group laboratory activities, as resource-based instructions; and (3) to test the statistically significant effect in the pre-service biology teachers' attitudes after being taught by animation-based instruction and small-group laboratory activities at private and public universities in Rwanda.

The study was guided by the following research questions :

1) Do the pre-service biology teachers' attitudes towards learning biology differ between private and public universities in Rwanda? 
2) How did the pre-service biology teachers' attitudes change after learning by animation-based instruction and small-group laboratory activities at private and public universities in Rwanda?

3) Is there any statistically significant effect of animation-based instruction and small-group laboratory activities as resource-based instructions on pre-service biology teachers' attitudes towards learning biology at private and public universities?

\section{The significance of the study}

The present study contributes significantly to the current literature by enriching the information related to the status of pre-service biology teachers' attitudes towards learning biology in higher learning institutions. It also emphasizes the role of resource-based instructions in improving pre-service biology teachers' attitudes towards learning biology. Further information would give pre-service biology teacher trainers some insight into the attitude characterizing pre-service biology teachers, thereby enabling them to decide which instructional method to apply when there is a need to improve their attitude towards learning biology. Furthermore, higher learning institutions, which train pre-service biology teachers would be better informed on the attitudes of pre-service biology teachers towards learning biology.

\section{The theoretical framework}

The study is grounded on reasoned action and planned behavior theories, as described by Ajzen Icek (1985). These theories assume that human behavior is sensibly based on the available information that might stimulate their feelings of liking or disliking. The theories postulate that humans react on the basis of their behavioral intention to perform, or not to perform, and then to act. The theories add that individual intention may change in time; and that they are determined by personal factors, which are the positive or negative decisions to perform a particular behavior. These factors define a person's attitude towards behavior that can be predicted from the knowledge of his or her attitude towards the object.

These theories are related to this study that aims to evaluate the attitudinal changes of students towards learning biology. These attitudinal changes may be perceived as students' changes in their feeling of like or dislike of learning biology after being treated with different resource-based instructions that, in this case, act as stimuli in the study.

\section{The Methodology}

This study used a survey design, in combination with an experimental design, whereby quasi-experimental and equivalent time series were used to check the pre-service biology teachers' attitude change after being taught by different instructional methods. The Survey design is one of the procedures in quantitative research, in which researchers may measure individuals' different aspects, such as behavior, attitudes, and opinions (Creswell, 2015). The survey was conducted before and after interventions given to groups of pre-service biology teachers. The design was used to permit the researchers to observe the changes in groups of preservice biology teachers after receiving different treatments. 


\subsection{Data-collection instrument and reliability}

A biology attitude scale developed by Russell and Hollander (1975) was adapted in this study in order to measure the pre-service biology teachers' changes in attitude towards learning biology. The scale was composed of fourteen (14) items or statements that were intended to measure the same behavior at a correlation of 0.80 to each item. The scale was rated from strongly agree (1) to strongly disagree (5); and it contained both negative and positive items. In this study, all items were administered to pre-service biology teachers; however, six (6) negative items were removed during the analysis after recognizing that pre-service biology teachers responded in the right way by positively agreeing to a positive statement and by negatively reacting to negative statements. Consequently, we recognized them as being opposite to positive items. For instance, items 2 and 3 are opposite to item 1 (see Table 1); item 6 is contrary to item 5 , which states that "Biology makes me feel secure; while at the same time, it is stimulating." Items 8 and 9 are contrary to item 7: "In general, I have a good feeling towards biology." Item 12 is contrary to items 11 and 12 (see Table 1). Therefore, a total of 6 negative items were removed from the analysis; and only eight positive items were considered (items 1, 4, 5, 7, $10,11,13,14)$. Before using the scale, its reliability was checked in the Rwandan context; and it was found to be 0.625 Cronbach alpha by the SPSS 23.0 version. This positive correlation confirmed the removal of negative-constructed items; and when considering all 14 items, the reliabilities tended to cancel each other out; and they provided a coefficient of nearly 0 in the negative direction.

Table 1: Biology attitude scale (Russell \& Hollander, 1975) [Note: 1 = strongly agree; 2 = Agree; 3 = Undecided; 4 = Disagree; and 5 = strongly disagree $]$

\begin{tabular}{|c|c|c|c|c|c|}
\hline Statements & 1 & 2 & 3 & 4 & 5 \\
\hline 1. Biology is very interesting to me. & & & & & \\
\hline 2. I don't like biology, and it scares me to have to take it. & & & & & \\
\hline 3. I am always under a terrible strain in a biology class. & & & & & \\
\hline 4. Biology is fascinating and fun. & & & & & \\
\hline $\begin{array}{l}\text { 5. Biology makes me feel secure, and at the same time, it is } \\
\text { stimulating. }\end{array}$ & & & & & \\
\hline $\begin{array}{l}\text { 6. Biology makes me feel uncomfortable, restless, irritable, and } \\
\text { impatient. }\end{array}$ & & & & & \\
\hline 7. In general, I have a good feeling towards biology. & & & & & \\
\hline 8. When I hear the word biology, I have a feeling of dislike. & & & & & \\
\hline 9. I approach biology with a feeling of hesitation. & & & & & \\
\hline 10. I really like biology. & & & & & \\
\hline 11. I have always enjoyed studying biology in school. & & & & & \\
\hline $\begin{array}{l}\text { 12. It makes me nervous to even think about doing a biology } \\
\text { course. }\end{array}$ & & & & & \\
\hline 13. I feel at ease in biology; and I like it very much. & & & & & \\
\hline $\begin{array}{l}\text { 14. I feel a definite positive reaction towards biology; it is } \\
\text { enjoyable. }\end{array}$ & & & & & \\
\hline
\end{tabular}




\subsection{Participants and data-collection procedures}

This survey study was conducted at two intentionally selected Universities that train pre-service biology teachers in Rwanda; a private university, (University of Technology and Arts of Byumba (UTAB), and the University of Rwanda College of Education (URCE), a solely public university that trains pre-service teachers. At these Universities, the study was conducted after an ethical check-up, and approval from the research unit at the University of Rwanda College of education, and with both Universities' permission. Pre-service biology was introduced to the study; and they signed the consent form voluntarily. The data were collected from February to April 2021.

The participants consisted of 50 pre-service biology teachers enrolled in Year (Level) two in the Faculty of Education, Department of Education in Sciences at UTAB. They formed a single group that received a pre-assessment survey; and after the group had been taught a course of biology (microbiology) by traditional methods (Lecture method), by animation-based instruction, and finally by laboratory methods through small-group laboratory activities. The teaching and learning time interval was three weeks, and after each session, they were postsurveyed by administering a Biology-Attitude Scale similar to that used in the preassessment. Thirty-four pre-service biology teachers responded positively to all the surveys, including pre-assessment, and their data were taken for analysis. At URCE, one hundred and eighty pre-service biology teachers enrolled in biology and chemistry education (BCE) Year-2; participated in the study. They were taken from a population of 528 pre-service biology teachers enrolled in the module of microbiology that was purposely selected for teaching by different resource-based instructions. They were randomly assigned to three groups, and each group was pre-assessed by a biology-attitude scale; and thereafter, it was treated at a particular time by the specific instructional method.

The first group was taught by the traditional method (lecture method), the second by animation-based instruction, while the third group was treated by laboratory methods through small-group laboratory activities. After those teaching sessions, each group responded to the similar post-Biology Attitude Scale.

\subsection{The Data analysis}

The data were entered into MS Excel 2016 and then filtered in order to track participants' full attendance throughout the intervention. The "COUNT IF" function was used to compute the number of answers, with either strongly agree, agree, undecided, disagree, or strongly disagree with each statement (for more details on how the data analysis was done, see our data deposited in Mendeley repository: "https:/ / data.mendeley.com/ datasets/bpfb5sdmyg/1"). The formula matches the answer provided by the respondent for each statement. Then, it counted all those who replied "1" as strongly agree, "2" as agree, "3" undecided, "4" Disagree, and "5" strongly disagree to each statement. After that, the software summed up the total agreements and all the disagreements to each statement. For the data collected from UR-CE, the analysis was done to both the pre-assessment and the post-assessment data of each of the three groups. The generated pre- 
assessment results of the groups (control group, animation group, and lab group) and their post-assessments results were presented on a plotted cluster-column graph, and they were then compared.

The same analysis was done to the data from UTAB, and the pre-assessment results, the results of the pre-service biology teachers after being taught by the lecture method, animation-based instruction, and laboratory methods through small-group laboratory activities, were compared by presenting them on a plotted cluster-column graph. To compare the private and the public pre-service biology teachers' attitudes towards learning biology and with the interventions given, we computed the averages and formed three scales by combining scale- 1 and scale-2, as well as scale- 3 alone, and then scale- 4 and scale- 5 together. We then considered the agreement rates among the pre-service teachers and the agreement rates across the interventions. We used the Chi-square test to compute the significance between the pre-service teachers and the intervention groups. This test was appropriate, as the actual count of the individual respondents was in place, instead of their scores.

\section{The Results}

Figure 1 compares the pre-service biology teachers' attitudes towards learning biology, before implementing the resource-based instructions to pre-service teachers at public and private universities. The quick insight is that the pre-service teachers hold positive attitudes towards biology. However, those at a private university (UTAB) hold considerably more attitude than those in a public university (URCE) (see Figure 1, blue and yellow colour of the cluster-column graph). Except on statement-7 and statement-14, public universities hold more attitudes than those from private universities. In general, pre-service teachers at URCE $(81 \%)$ have a better feeling towards biology than do those at UTAB (79\%) [see Statement-7]. Likewise, they (81\% of URCE pre-service biology teachers) "feel a definite positive reaction to biology; since it is enjoyable" in contrast to those at UTAB (74\% of UTAB pre-service teachers) [see Statement-10]. 


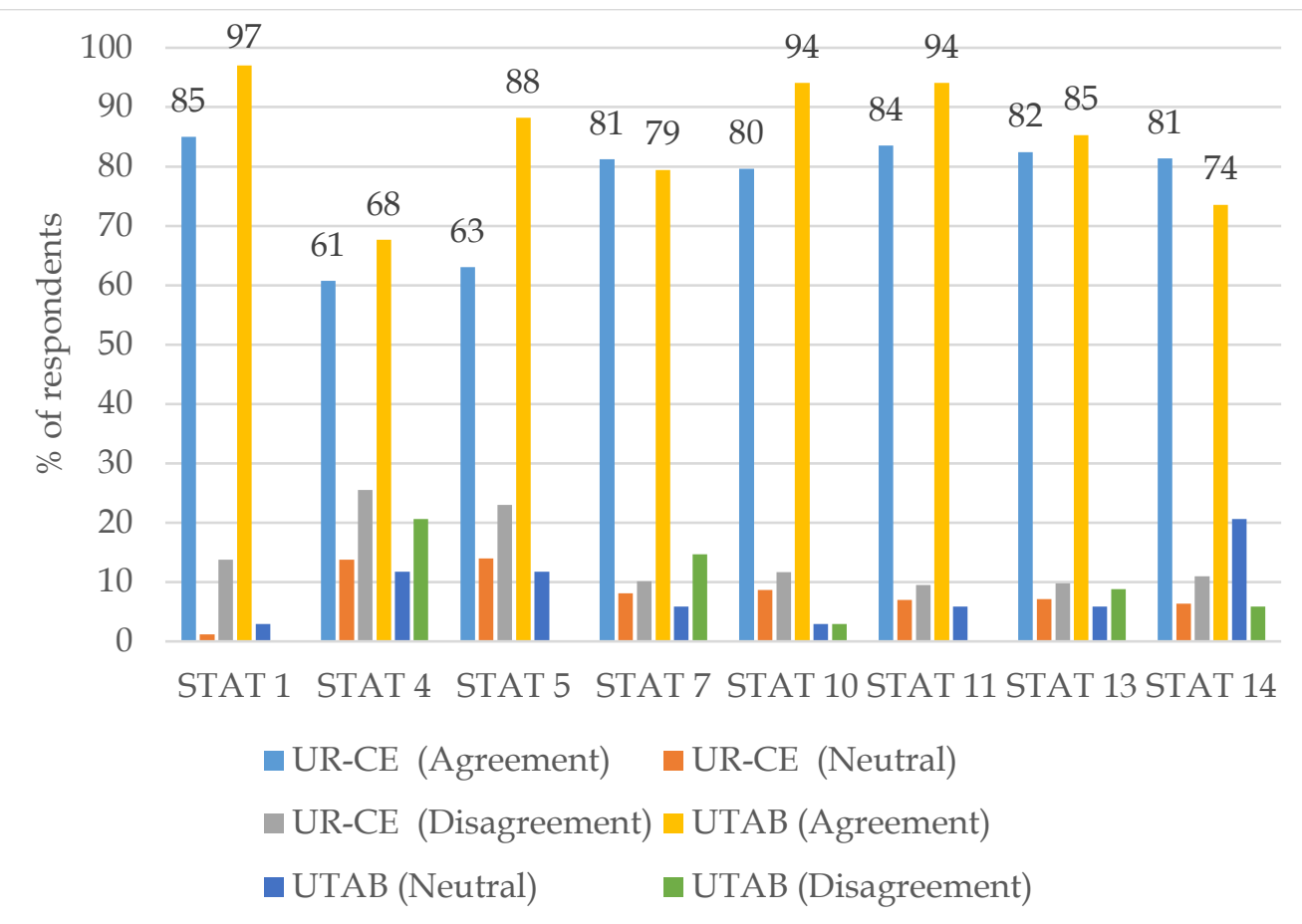

Figure 1: Attitude of Pre-service Biology teachers at a public and private university towards learning Microbiology. [Note: Cluster columns show the distribution of preservice biology teachers into 3 groups: an agreement, neutral, and disagreement scales. The vertical axis displays their percentage rates, while the horizontal axis displays their attitude statements.]

Biology is very interesting ( $97 \%$, see Statement- 1$)$, fascinating and fun $(68 \%$, see Statement-4), and this makes the UTAB pre-service teachers feel secure, while at the same time stimulated ( $88 \%$, see Statement-5) more than URCE pre-service biology teachers. Similarly, UTAB pre-service teachers "really like biology" (94\%, see Statement-10), and they enjoy studying biology at school (94\%, see Statement$11)$, and they feel at ease in biology and like it very much (85\%, see Statement-13) more than do the URCE pre-service teachers. Despite these variations in attitude, however, the Chi-square test shows no statistically significant difference between URCE and UTAB pre-service teachers, as regards their attitudinal statements $\left(X^{2}\right.$ $=48, d f=47(1), p=0.243)$.

Figure 2 shows the attitude results from URCE pre-service teachers before and after learning biology. It is worth mentioning that we only considered the positive statements in our analysis. Thus, eight out of 14 attitude statements are under consideration (see the detailed explanation in the methodology section). The URCE pre-service teachers' attitudes towards biology were computed in the three groups of intervention of resource-based instruction (RBI) after being taught in those modes. Figure 2 displays two sides. The side on the left is before the assessment, while the one on the right side is after the intervention. The first group is the control group or the lecture group, the second is the animation group, and the third group is the lab-based group. 
The figure is a cluster-staked graph. Thus, it accumulates both agreement, neutral, and disagreement scales at the $100 \%$ rate. For instance, 59 pre-service teachers participated via the control group in the pre-assessment stage; 40 were in agreement, with one being neutral; while 18 fell into the disagreement category. Thus, $68 \%$ agreed, $2 \%$ were neutral, and 30\% disagreed with the first statement [Biology is very interesting to me], and these taken together equate to $100 \%$ (see Figure 2).

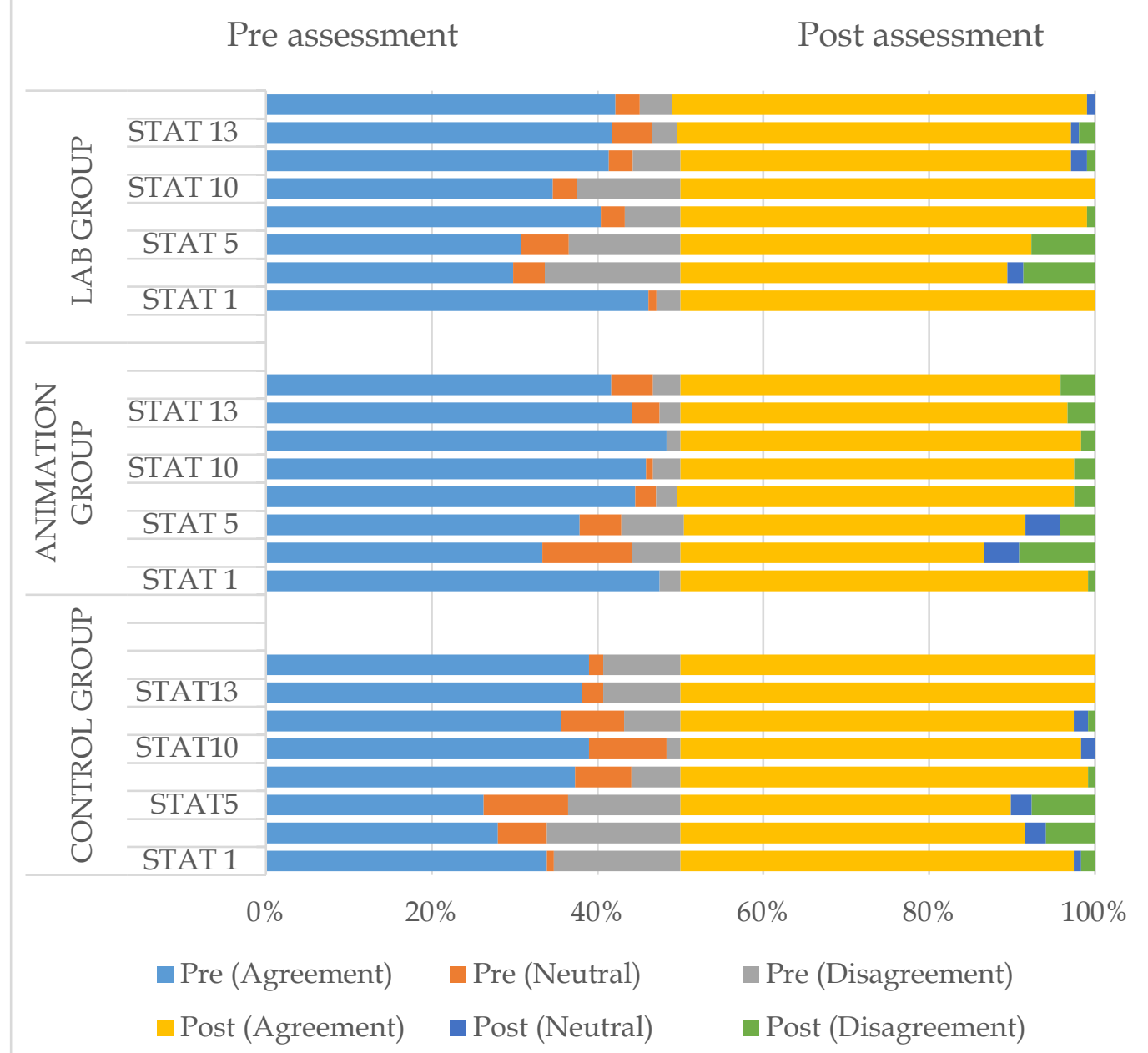

Figure 2: The Attitude of Pre-service Biology teachers at a public university before and after learning Microbiology. [Note: N: 59 for the control group, $\mathrm{N}=60$ for the animation group, and $\mathrm{N}=52$ for the lab group]

The attitude change did not significantly differ between the teaching interventions (see Table 2). However, the pre-service teachers' attitudes towards biology changed after instruction in all the groups across all the attitude statements, irrespective of the use of the animation, laboratory, and lecture instructions. For instance, statement- 4 [Biology is fascinating and fun] shifted from $56 \%$, who had a positive attitude and reached $83 \%$ after being taught in the traditional mode. On the same statement, $67 \%$ of the pre-assessment teachers had a positive attitude, or they agreed with the statement; and this increased to $73 \%$ after learning through animation-based instructions.

Similarly, the lab-based activities increased the positive attitudes towards biology from $60 \%$ to $79 \%$ of pre-service biology teachers (see Figure 2). 
Table 2: Statistical significance between intervention groups at URCE.

\begin{tabular}{llllll}
\hline & Pre-test & Post-test & $\mathbf{X}^{\mathbf{2}}$ & $\mathbf{d f}$ & $\boldsymbol{p}$-value \\
\hline $\mathbf{1}$ & Control group & Control group & 34 & 30 & 0.281 \\
\cline { 3 - 6 } & & Animation group & 42 & 36 & 0.227 \\
\cline { 3 - 6 } & Laboratory group & 28 & 24 & 0.260 \\
\hline \multirow{2}{*}{ Animation group } & Control group & 34 & 30 & 0.281 \\
\cline { 3 - 6 } & & Animation group & 42 & 36 & 0.227 \\
\cline { 3 - 6 } & Laboratory group & 28 & 24 & 0.260 \\
\hline \multirow{3}{*}{ Laboratory group } & Control group & 35 & 25 & 0.094 \\
\cline { 3 - 6 } & & Animation group & 32 & 30 & 0.368 \\
\cline { 3 - 6 } & Laboratory group & 27 & 20 & 0.145 \\
& & & & &
\end{tabular}

Note: $\mathrm{X}^{2}$ is the Chi-square value, $\mathrm{df}$ is the degree of freedom, a $\mathrm{p}$-value is computed, based on a 0.05 level of significance or on a $95 \%$ confidence interval.

Figure 3 shows the results of the UTAB pre-service teachers. In this case, a timeseries design was used. Thus, attitudinal change was measured quince across four stages of one group of pre-service teachers. The attitude does not seem to change from pre-assessment to another stage of intervention, such as lecture, animation, or lab-based instruction. Statement- 4 and statement- 5 seem to be persistent across all the interventions. The understanding of the statements might be the reason for this.

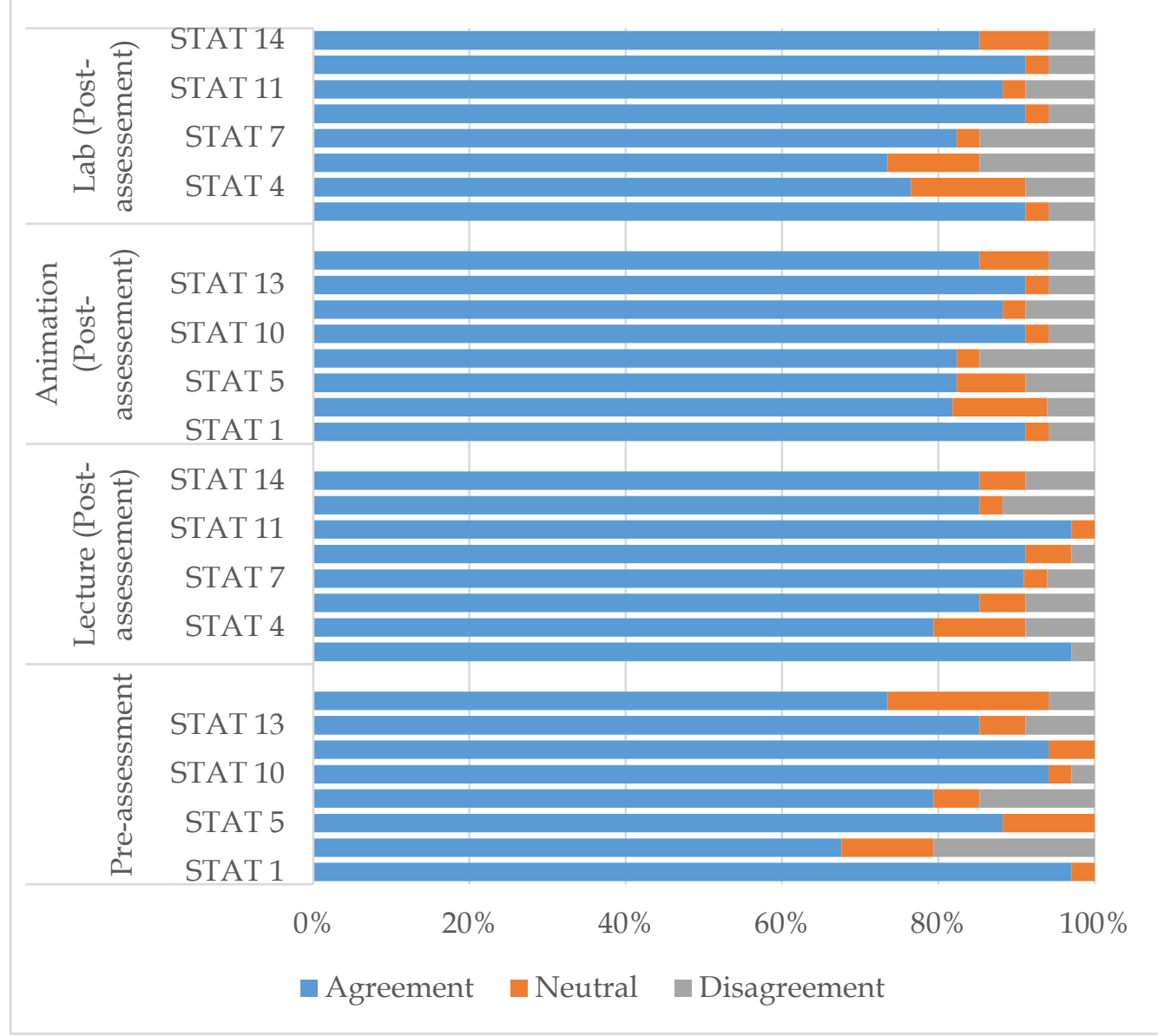

Figure 3: The Attitude of Pre-service Biology teachers at a private university before and after learning Microbiology. [Note: $\mathrm{N}=34$ both at re-assessment and continuous intervention] 
Table 3 shows how the interventions made no statistically significant differences in the attitude between the pre-assessment and the pre-service biology teachers at UTAB. Neither did their attitude change from pre-assessment to lecture, animation, laboratory instruction, lecture instruction to animation, or to laboratory instruction. It changed, however, from animation to laboratory instruction at a $p<0.05$ (see Table 3).

Table 3: Statistically significant different effects between the series of interventions at UTAB.

\begin{tabular}{llllll}
\hline & Prior series & Next series & $\mathbf{X}^{\mathbf{2}}$ & $\mathbf{d f}$ & $p$-value \\
\hline $\mathbf{1}$ & Pre-assessment & Lecture instruction & 26 & 24 & 0.353 \\
\cline { 3 - 6 } & $\begin{array}{l}\text { Animation } \\
\text { instruction }\end{array}$ & 27 & 24 & 0.320 \\
\cline { 3 - 6 } & $\begin{array}{l}\text { Laboratory } \\
\text { instruction }\end{array}$ & 35 & 30 & 0.255 \\
\hline $\mathbf{2}$ & Lecture instruction & $\begin{array}{l}\text { Animation } \\
\text { instruction }\end{array}$ & 17 & 16 & 0.393 \\
\cline { 2 - 6 } & $\begin{array}{l}\text { Laboratory } \\
\text { instruction }\end{array}$ & 22 & 20 & 0.329 \\
\hline $\mathbf{3}$ & Animation instruction & $\begin{array}{l}\text { Laboratory } \\
\text { instruction }\end{array}$ & 32 & 20 & 0.043 \\
\hline
\end{tabular}

Note: $\mathrm{X}^{2}$ is the Chi-square value, $\mathrm{df}$ is the degree of freedom, the $\mathrm{p}$-value is computed, based on a 0.05 level of significance, or on a $97 \%$ confidence interval.

\section{Discussion}

With research question one, the study sought to identify the pre-service biology teachers' attitudes towards learning biology at a private University (UTAB) and at a public University (UR-CE) before any interventions. Although they both presented a positive attitude, and that a statistically non-significant difference in attitude towards the statements was revealed, pre-service biology teachers at the private University (UTAB) show considerably more attitude than do those in a public university (URCE).

The difference in pre-service biology teachers' attitudes at private and public universities may be explained by many facts. From these results, one can consider how private and public university pre-service biology teachers are enrolled in biology subjects. Pre-service biology teachers select biology subjects within their wide choice at the private University; whereas at a public teacher-training university, students are enrolled in biology programs, based on the combination they learned at secondary schools. Those at a Public University may be enrolled in Mathematics, Biology Education, or Biology Chemistry education; while on the basis of choice, they could decide to learn subjects other than biology, such as Mathematics and Chemistry.If this happens, the pre-service biology teachers would follow the program with much effort in one subject that is interesting to him or her, but with a low attitude or negative attitude towards biology, where the subject was just presented without any individual choice. Related studies that compared students' attitudes at private and public schools or universities are still very rare; however, looking into other domains, such as the motivation towards learning biology, the study of Bernardo et al. (2015) advocated a difference in 
motivational level towards learning science between public and private-school students. Related studies that compared students' attitudes at private and public schools or universities are still very rare.

Apart from the statistical results, in reality, the pre-service biology teachers at the private university presented a higher positive attitude towards learning biology than did their colleagues at a public university. This implies that they might also perform differently in biology. The recommendation to the Government is to ensure that all students are oriented towards Biology education at the public University (UR-CE); and that they hold a positive attitude towards learning biology. Additionally, the orientation on the basis of the student's subject choice should be more emphasized.

Although the pre-service, biology teachers at public universities presented a low level of attitude; they showed a good feeling and a more positive reaction towards biology than did those in private universities. Furthermore, they perceived biology as an enjoyable science subject. This may be explained by the fact that they learned in different physical and classroom environments, where public preservice biology teachers learn in a more diverse environment, with different biological stimuli than those in a private university.

A long time ago, it was noted that the classroom environment presented more relation with the student's attitude towards a science that includes biology (Talton \& Simpson, 1987). The findings relate with those of other studies, such as those of Nordqvist and Johansson (2020), Prokop, Prokop, et al. (2007), Prokop, Tuncer, et al. (2007), and Sanders and Morrison-Shetlar (2001). They noted that, in general, students have a positive attitude towards biology. Indeed, the present study's findings did not show any change of attitude, despite the instructions used. The theory of reasoned action and planned behaviour (Ajzen, 1985), which directed this study confirms the obtained results; as it concludes the final students' agreement or disagreement in terms of having a positive or negative attitude towards learning biology as a subject.

We identified how the pre-service biology teachers' attitude changes after being taught by different instructional methods, at both private (UTAB) and public (UR$\mathrm{CE}$ ) universities. The data form the public university did not show any data that revealed any statistically significant difference in attitudinal change between preservice biology teachers - taught by the traditional (lecture) method, animationbased instruction, and taught by laboratory methods via small-group laboratory activities. However, instructions improved the pre-service biology teachers' attitudes differently across all the attitudinal statements.

The fact that both the instructional methods improved the pre-service biology teachers' attitude to the positively considered statements may be explained by the exciting qualities of microbiological content, used during the intervention. This study agrees with our previously published results, where we found that all the resource-based interventions improved pre-service biology teachers' academic achievement in Rwanda (Mukagihana et al., 2021b). Consequently, attitude may correlate with the performance of the students. The findings deviate from what 
other studies identified, where traditional methods of teaching (lecture) did not improve the students' attitude towards learning biology, such as did active instructions, like computer-aided instruction, co-operative learning methods (Rabgay, 2018; Yesilyurt et al., 2019).

Although the three groups were taught by using different instructional methods at the public University (UR-CE), pre-service biology teachers learned the same content. Consequently, in each instruction, new knowledge was gained; and this added to their pre-existing attitude, thus changing the mind or beliefs of one who responded negatively to the statement before teaching, to agree with the statements positively. This makes pre-service biology teachers present a positive attitude on some statements after receiving interventions. The implication is that both lecture methods and animation-based instructions could improve preservice biology teachers' attitudes towards learning biology. However, animationbased instructions and small-group laboratory activities may do more; since they are resource-based instructions that create an active learning environment that attracts students in the teaching and learning process.

The findings of the study are in line with those of other studies (Akinbadewa \& Sofowora, 2020; Akinoğlu \& Tandoğan, 2007; Koksal \& Berberoglu, 2014; Sen \& Oskay, 2016, (Akinbadewa \& Sofowora, 2020; Akinoğlu \& Tandoğan, 2007; Çepni et al., 2006; Koksal \& Berberoglu, 2014; Rabgay, 2018). These studies tested the effect of instructional methods, like technology-based instructions and laboratory methods on students' attitude towards biology, whereby such instructional methods improved students' attitudes towards science, including biology.

In particular, our study showed that even the lecture method could improve the pre-service biology teachers' attitudes. This is because pre-service teachers are mature enough; and they have to study the subject; since they will probably be teaching it after their program. Thus, the fact that they plan to teach that subject in their future career, the attitude to learning improves, despite the instructional method used to deliver it. The implication is that after learning, pre-service biology teachers knew their attitude towards biology - whether it is very interesting to them, or not. It was noted that students, when learning by the lecture method, develop their listening capacity; and they can master and maintain concepts (McManus et al., 2003); thus, it is easy for them to decide on their opinion.

Conversely, the findings disagree with those of Koksal and Berberoglu (2014), who noticed that there were no improvements in students' attitude after learning via the traditional methods. Therefore animation-based instruction and smallgroup laboratory activities are recommended for improving pre-service biology teachers' attitudes towards learning biology.

At the private University (UTAB), the attitude change was measured in a single group of pre-service biology teachers, who received a pre-assessment test by responding to the biology-attitude scale, and a post-assessment test, after receiving treatment through a series of instructions. Looking into the results, we 
found that pre-service biology teachers maintain their positive attitude - both before and after a series of interventions. There were no significant differences in attitude change after a series of instructions, except animation to laboratory instruction. However, each series of instructions changed their agreement on statements.

Small-group laboratory activities statistically improved pre-service biology teachers' attitude towards learning biology, thereby showing that those preservice biology teachers are eager to learn, understand the biological concepts, and become familiar with laboratory experiments, which they are expected to reflect during their teaching in their future career. Indeed, the very recent study by Uwamahoro et al. (2021) conducted in Rwanda has shown that laboratory activities improve students' understanding of concepts through appropriate hands-on activities. Therefore, laboratory methods should be emphasized at private universities to develop pre-service biology teachers' scientific skills and improve their attitude towards learning biology, thereby improving their performance.

\section{Conclusion, limitations, and further research}

The present study aimed to identify how the pre-service biology teachers' attitude changed due to animation-based instruction and small group laboratory activities as resource-based instructions at private and public universities in Rwanda. The study compared their attitude towards learning biology before teaching sessions; and it revealed that both groups of pre-service biology teachers present a positive attitude towards learning biology. However, based on the differences in positive agreement towards statements and in their feelings towards biology, pre-service biology teachers at the private University (UTAB) were found to have much more positive attitudes than those in a public university (URCE).

At a public university, pre-service teachers' attitudes towards biology changed after instruction in all groups across all the attitudinal statements. However, in private, the pre-service biology teachers' attitudes towards learning biology did neither change from pre-assessment, nor after all the series of interventions. There was no statistically significant difference in attitudinal change between the treatment groups at both public and private universities. The attitudinal change did not show any statistically significant differences between teaching interventions at either public or private universities.

After teaching the interventions, the results revealed that both lecture methods, animation-based instructions, and laboratory methods through small-group laboratory activities equally improved pre-service biology teachers' attitudes towards learning biology. Nevertheless, via time-series design, laboratory activities showed a great attitudinal change. This unique finding reveals that preservice biology teachers are mature enough to study through any instructional method. They develop a positive attitude, since they would also teach the same subject in their future career. 
Given that the present study used different designs during the interventions and a non-equivalent quasi-experimental design and equivalent time series at a public university (UR-CE) and at a private university (UTAB). we did not compare the pre-service biology teachers' attitudinal changes after the interventions at both universities. Therefore, further research should focus on the use of single and similar designs at both Universities. Furthermore, the study did not consider the gender difference in pre-service biology teachers' attitudes before and after the interventions. This information may give insight to trainers about the status of gender difference; consequently, they should be able to know which gender needs more emphasis to improve their attitude towards biology. Future research is required to highlight pre-service biology teachers' gender differences in attitude towards biology and improve their attitude towards learning and teaching biology. This is, therefore, recommended.

\section{Acknowledgments}

We would like to thank the Directorate of Research and Innovation at the University of Rwanda College of education (URCE) and the University of Technology and Arts of Byumba (UTAB) for granting ethical clearance and permission to conduct this study. Also, we sincerely thank the African Center of Excellence for Innovative Teaching and Learning Mathematics and Science (ACEITLMS) for the financial support provided to successfully conduct this study.

\section{References}

Akinbadewa, B. O., \& Sofowora, O. A. (2020). The effectiveness of multimedia instructional learning packages in enhancing secondary school students' attitudes towards biology. International Journal on Studies in Education, 2(2), 119-133. https://doi.org/10.46328/ijonse.19

Akinoğlu, O., \& Tandoğan, R. Ö. (2007). The effects of problem-based active learning in science education on students' academic achievement, attitude and concept learning. Eurasia Journal of Mathematics, Science and Technology Education, 3(1), 7181. https:// doi.org/10.12973/ejmste/75375

Bernardo, A. B. I., Ganotice, F. A., \& King, R. B. (2015). Motivation gap and achievement gap between public and private high schools in the Philippines. Asia-Pacific Education Researcher, 24(4), 657-667. https://doi.org/10.1007/s40299-014-0213-2

Çepni, S., Taş, E., \& Köse, S. (2006). The effects of computer-assisted material on students' cognitive levels, misconceptions and attitudes towards science. Computers and Education, 46(2), 192-205. https://doi.org/10.1016/j.compedu.2004.07.008

Hussein, Z. (2017). Leading to Intention: The role of attitude in relation to technology acceptance model in e-Learning. Procedia Computer Science, 105(December 2016), 159-164. https://doi.org/10.1016/j.procs.2017.01.196

Koksal, E. A., \& Berberoglu, G. (2014). The effect of guided-inquiry instruction on $6^{\text {th }}$ Grade Turkish students' achievement, science process skills, and attitudes toward science. International Journal of Science Education, 36(1), 66-78. https://doi.org/10.1080/09500693.2012.721942

Mbonyiryivuze, A., Yadav, L. L., \& Amadalo, M. M. (2021). Students' attitudes towards physics in Nine Years Basic Education in Rwanda. International Journal of Evaluation and Research in Education (IJERE), 10(2), 648-659. https://doi.org/10.11591/ijere.v10i2.21173

McManus, D. O., Dunn, R., \& Denig, S. J. (2003). Effects of traditional lecture versus 
teacher-constructed \& student constructed self-teaching instructional resources on short-term science achievement \& attitudes. The American Biology Teacher, 65(2), 93-102. https://doi.org/10.2307/4451447

Nordqvist, O., \& Johansson, S. (2020). Secondary school biology students' attitudes towards modern biotechnology characterised using structural equation modeling. Eurasia Journal of Mathematics, Science and Technology Education, 16(2).

Prokop, P., Prokop, M., \& Tunnicliffe, S. D. (2007). Is biology boring? Student attitudes toward biology. Journal of Biological Education, 42(1), 36-39. https:// doi.org/10.1080/00219266.2007.9656105

Prokop, P., Tuncer, G., \& Chudá, J. (2007). Slovakian students' attitudes toward biology. Eurasia Journal of Mathematics, Science and Technology Education, 3(4), 287-295. https:// doi.org/10.12973/ ejmste/75409

Rabgay, T. (2018). The effect of using co-operative learning method on tenth grade students' learning achievement and attitude towards biology. International Journal of Instruction, 11(2), 265-280. https:/ / doi.org/10.12973/iji.2018.11218a

Russell, J., \& Hollander, S. (1975). A biology attitude scale. American Biology Teacher, 37(5), 270-273. https://doi.org/10.2307/4445229

Sanders, D. W., \& Morrison-Shetlar, A. I. (2001). Student attitudes toward web-enhanced instruction in an introductory biology course. Journal of Research on Computing in Education, 33(3), 251-262. https:// doi.org/10.1080/08886504.2001.10782313

Sen, S., \& Oskay, O. O. (2016). The effects of 5E inquiry learning activities on achievement and attitude toward chemistry. Journal of Education and Learning, 6(1), 1. https://doi.org/10.5539/jel.v6n1p1

Talton, E. L., \& Simpson, R. D. (1987). Relationships of attitude towards classroom environment with attitude towards and achievement in science among tenth grade biology students. Journal of Research in Science Teaching, 24(6), 507-525. https://doi.org/10.1002/tea.3660240602

Ukobizaba, F., Ndihokubwayo, K., \& Uworwabayeho, A. (2020). Teachers' behaviours towards vital interactions that attract students' interest to learn mathematics and career development. African Journal of Educational Studies in Mathematics and Sciences, 16(1), 85-94.

Uwamahoro, J., Ndihokubwayo, K., Ralph, M., \& Ndayambaje, I. (2021). Physics students' conceptual understanding of geometric optics: Revisited analysis. Journal of Science Education and Technology, 30(0123456789), 1-13. https://doi.org/10.1007/s10956-021-09913-4

Yesilyurt, M., Dogan, M., Acar, M., Doğan, M., \& Acar, S. M. (2019). The meta-analysis of the effect of computer-aided instruction on students' attitudes in science and mathematics. Acar, S Journal of Primary Education, 1(2), 57-69. https://dergipark.org.tr/en/pub/temelegitim/issue/44423/542243 